\title{
Delineating the Academic Atmosphere in Pandemic Era Through the Implementation of School from Home
}

\author{
Habiba Al Umami ${ }^{*}$, Deny Efita Nur Rakhmawati², Badruddin³, Dwi Cahyo Kartiko ${ }^{4}$ \\ ${ }^{1}$ UIN Maulana Malik Ibrahim Malang, Indonesia \\ ${ }^{2}$ UIN Maulana Malik Ibrahim Malang, Indonesia \\ ${ }^{3}$ UIN Maulana Malik Ibrahim Malang, Indonesia \\ ${ }^{4}$ Universitas Negeri Surabaya, Indonesia \\ *Corresponding author. Email: habibaalumami@uin-malang.ac.id
}

\begin{abstract}
Education is an importance aspect in our life. It does not stop even when pandemic hits worldwide. An innovation of online learning is implemented to maintain the educational practice. "School from home", the term we use to describe the online teaching-learning process, has created such controversy because of parent's protest towards the practice. This study aims to describe the portrayal of online learning system by analysing WhatsApp chats between teacher and parent that become viral on the digital space. The study adopts qualitative research method and Theme and Rheme frameworks to get the result of analysis. The analysis reveals that the successful current online learning system is hard to achieve because the education's culture has shown the exclusivity of parents in the given discourse. This exclusivity has indirectly created unconducive environment for the students in gaining knowledge.
\end{abstract}

Keywords: Theme, Rheme, Education, School from Home, Covid-19

\section{BACKGROUND}

Covid-19 pandemic has changed our life routines in all aspects, especially in the educational system. Since the spread, government, parents, and all the educational system stakeholders have concerned about children's health and safety. It is the main reason for the government to conduct the online teaching-learning process at all education levels. "School from home" is a popular term to describe the online teaching-learning process done by elementary students up to university students. In times like this, the students need more than just the teacher's instruction, school book, and internet to run their school's activity. They need their parents at home also to be active stakeholders to help them in learning. It is what challenges us nowadays.

Before the pandemic, parents are children's supporting system in learning. As the name suggests, the supporting system means that parents are not active stakeholders in the teaching-learning process. Yet indeed, still, there are some parents who choose to teach their children after they come from school or even choose to teach them in homeschooling methods. Yet, the number of parents is not much - parents' urge to take an active role in the teachinglearning process before a pandemic is not obligatory. Most parents lean on teacher's contributions than their own in terms of education.

The shift in the teacher-parent role in today's teachinglearning process is the main reason for conducting this study. Some parents who are not ready to take a position as teachers for their students raise complaint issues via WhatsApp application to the schools and teachers. Their complaints then become viral on Instagram.

Following the phenomenon above, this study is conducted to delineate the current online school 
phenomenon due to covid-19. In addition to describing the phenomenon, this study also highlights the discourse of the parent's role in online learning. The analysis is done within the linguistics analysis framework using Theme and Rheme theory under the qualitative approach. This theory is utilized because this theory helps us uncover which message is being emphasized by the speaker. Thus, it helps us to portray and even evaluate the academic situation in Indonesia within the pandemic.

There are several studies focused on the role of parent in the students' activity. Sapungan and Sapungan (2014) in their paper entitled Parental Involvement in Child's Education: Importance, Barriers and Benefits highlights that parent's role has big influence on the children's development and it is seen as a substantial element in the children's development [1]. Ceka and Murati (2016) bring the discussion into the smallest group of society, family. They believe that family has an obligation to create an environment that could boost the children's personality. Yulianti et al. (2019) drew research on Indonesian schools in urban and rural Java regarding to the parent's involvement in the matter of children education [3]. They come to a conclusion that Socio-economic background has led to different perspectives of parents in viewing the importance of education. This has led a different pattern of parent's involvement.

Not to mention, several studies is also conducted under the Theme Rheme theory to uncover the core discourse of the text. Potter (2016) analysed the ideological representations through Theme and Rheme in English and Arabic news reports portraying

Syria under the Systemic Functional Approach [4]. The results confirm that Halliday's Theme and Information systems enable them to discover the meaning-potential in Arabic clauses and detect the underlying ideologies in English and Arabic news reports. Stella and Gunawan (2017) observes the Theme and Rheme used in the fivestar hotels websites in Surabaya [5]. They claim that in organizing the hotels' information, they place the Theme and Rheme intentionally. Sinaga (2019) also analysed Theme and Rheme on Jakarta Post newspaper. The result finds that Topical Theme are mostly used in organizing the message in the newspaper [6].

\section{LITERATURE REVIEW}

The way we put information in a clause reflects where the clause is coming from and where it goes [7]. The beginning of a clause refers to what the clause is about or the information derived from the clause. It links to the information gained from the previous clause. In English, Theme is defined by the elements that come first in the sentence representing a point of departure of the previous message [7]. Meanwhile, the rest of the sentence is regarded as a Rheme because it adds information, which is not there before [7].

These two terms characterized the way information is distributed [8]. In text, Theme mirrors the given information that has been mentioned before or mutually shared by the participant in the immediate context [9]. Meanwhile, Rheme indicates the new information that the audience does not know. Still, it somehow needs to know in order to gather the holistic information or follow the progression of the argument [10]. Specifically, Theme refers to the writer's topic, and Rheme denotes his opinion regarding the topic.

A speaker can utilize thematic and information structures to create meanings based on his perspectives and influence the public discourse [11]. This because the structure of information depends on the structure of thematic expression. However, the information system is not the clause, it is a separate grammatical unit consist of Given and New [12]. Given is an element of the information units that is known and mutually shared by the stakeholder in the discourse. Meanwhile, New element is a unit that is unknown or unpredictable before. Through this system, the speaker can choose which information is placed under the Given and New units [11]. These choices are made based on the speaker's projection towards particular point of view.

\section{METHODS}

This study is conducted under the qualitative method. This study's data source are several screenshots of WhatsApp chat of Indonesian parents that become viral on Instagram. The data are the utterances on the screenshots. Since Theme and Rheme's framework is discussed under the concept of English, the data is translated into English before they are analysed. As the first step, the analysis is done by classifying the Theme and Rheme of the clause and the Given and New information. This step is done to reveal which textual unit in the text belongs to what classification. After that, the discussion is brought into a bigger scope of the parent's role in the children's academic activity and Indonesia's education context. 


\section{FINDINGS AND DISCUSSION 4.1. Findings}

There are 4 conversations that belong as the data of this study. Each conversation is analysed based on their following context.

Table 1: Analysis on Conversation 1

\begin{tabular}{|l|l|l|}
\hline Speaker & Theme & Rheme \\
\hline $\begin{array}{l}\text { Teacher } \\
\text { T1 })\end{array}$ & $\begin{array}{l}\text { If you don't } \\
\text { have any } \\
\text { (media), } \\
\text { (Th1.1) }\end{array}$ & $\begin{array}{l}\text { we would ask the } \\
\text { students to play } \\
\text { football because } \\
\text { back when in } \\
\text { school, not all } \\
\text { students could } \\
\text { catch and throw } \\
\text { the ball properly. } \\
\text { (Rh1.1) }\end{array}$ \\
\hline $\begin{array}{l}\text { Parent } \\
\text { P1) }\end{array}$ & $\begin{array}{l}\text { There's no ball } \\
\text { at home } \\
\text { (Th1.2) }\end{array}$ & $\begin{array}{l}\text { Don't ask too } \\
\text { much. Only } \\
\text { making homework } \\
\text { has stressed me } \\
\text { out. (Rh1.2) }\end{array}$ \\
\hline $\begin{array}{l}\text { Teacher } \\
\text { (T1) }\end{array}$ & $\begin{array}{l}\text { Sorry mommy, } \\
\text { this is not too } \\
\text { much. (Th1.3) }\end{array}$ & $\begin{array}{l}\text { This is a } \\
\text { grossmotor } \\
\text { activity for the } \\
\text { students. You can } \\
\text { just use the } \\
\text { simplest media at } \\
\text { home. (Rh1.3) }\end{array}$ \\
\hline Parent & $\begin{array}{l}\text { I (Th1.4) } \\
\text { have cooking pot. } \\
\text { (Rh1.4) }\end{array}$ \\
\hline
\end{tabular}

In the $1^{\text {st }}$ conversation, the chat is about using the media for grossmotor activity at home. T1 politely asks for football activity to the P1. The topic for the discussion is drawn through the Th1.1. Through this part, both of T1 and P1 shared mutual knowledge that the goal of their conversation is to discuss the activity for the students. The information that has not been mutually shared is reflected in the Rh1.1 in the form of offer. However, T1 statement was directly rejected by $\mathrm{P} 1$ through the use of negation. The negation is placed as the Theme (Th1.2). This implies that parent's rejection towards teacher's instruction is not something new. This speculates that both of P1 and T1 may aware that parents would not do as the teacher's instruction in conducting online learning or school from home. In addition to the rejection, the parents also highlight New information in Rh1.2 which is assumed that the teacher has not known this information. The parent claims that the teacher has gone beyond of the parent's capability (Rh1.2). Seeing the claims in Rh1.2, the teacher negates the statement by implying that his request is a normal request and lower the standard of media used in grossmotor activity by letting the parents choose the simplest one they can get (Th1.3 and Rh1.3). Though this demand is not negated or rejected but the P1 statements in Rh1.4 implies a sarcastic refutation in declining the offer by stating "cooking pot". Through the conversation above, all the $\mathrm{T} 1$ requests towards $\mathrm{P} 1$ have been declined and refuted. The refutation can be seen through the order of the information. Every Rheme of $\mathrm{T} 1$ is negated in the Theme of P1. This implies that the parent does not want to take role as the teacher.

While the $1^{\text {st }}$ conversation reflects about the media used in online school or school from home activity, the $2^{\text {nd }}$ conversation highlights more about the parent's condition in taking the role as an educator.

As reflected in Rh2.1, T2 brings the focus of the conversation on the learning media used in the online school. However, P2 counter the statement by putting herself as the Th2.2 and stating the information of the learning media as the Rh2.2. This implies that P2 wants to shift the focus of the discussion. P2 struggle in shifting the discussion focus is seen through her feelings and condition drawn in both of her Theme and Rheme. Not to mention, T2 requests such as in Th2.1 and Th2.8 is rejected by $\mathrm{P} 2$. Her rejections are not expressed through her Theme but on her Rheme by emphasizing her situations. This indicates that P2 is eager to make T2 understand her feelings and positions as the educator on online learning. It is not the learning media as the main problem in the implementation of online school but the transitional shift from parent to teacher as the educator that drains her. She even threatens the school to give compensation as the responsibility thrown to the parents. As parents, she claims that she could refuse the school's instruction to take care of the school assignment as in Rh2.5. Specifically, in Th2.6 and Rh2.6, P2 has made clear distinction in the discourse. When the child has his role as students, P2 emphasize that the responsibility goes to the teacher, not the parent.

As if media and role distribution are not enough to be seen as the prime cases on online learning situation, $3^{\text {rd }}$ conversation reveals another factor burdening the parents, which is school fee. 
Table 2: Analysis on Conversation 2

\begin{tabular}{|c|c|c|}
\hline Speaker & Theme & Rheme \\
\hline $\begin{array}{l}\text { Teacher } \\
\text { (T2) }\end{array}$ & Mom, (Th2.1) & $\begin{array}{l}\text { try to use laptop \& } \\
\text { Google Chrome } \\
(\mathrm{Rh} 2.1)\end{array}$ \\
\hline $\begin{array}{l}\text { Parent } \\
(\mathrm{P} 2)\end{array}$ & I (Th2.2) & $\begin{array}{l}\text { want to slam my } \\
\text { laptop already } \\
(\mathrm{Rh} 2.2)\end{array}$ \\
\hline $\begin{array}{l}\text { Teacher } \\
\text { (T2) }\end{array}$ & $\begin{array}{l}\text { Be patient } \\
\text { (Th2.3) }\end{array}$ & $\begin{array}{l}\text { Mom (grinning } \\
\text { face with squinting } \\
\text { eyes and sweat } \\
\text { drop emoticon) } \\
\text { (Rh2.3) }\end{array}$ \\
\hline \multirow[t]{4}{*}{$\begin{array}{l}\text { Parent } \\
\text { (P2) }\end{array}$} & \multirow[t]{2}{*}{ Later, (Th2.4) } & $\begin{array}{l}\text { I will ask for } \\
\text { psychiatric fee } \\
\text { from the school. }\end{array}$ \\
\hline & & (Rh2.4) \\
\hline & $\begin{array}{l}\text { If you still } \\
\text { distress me, } \\
(\mathrm{Th} 2.5)\end{array}$ & $\begin{array}{l}\text { I don't want to } \\
\text { take care of any } \\
\text { school assignment } \\
\text { anymore }(\mathrm{Rh} 2.5)\end{array}$ \\
\hline & $\begin{array}{l}\text { It's my kids } \\
\text { who is your } \\
\text { students. } \\
\text { (Th2.6) }\end{array}$ & $\begin{array}{l}\text { Why do you have } \\
\text { to burden me? } \\
\text { (Rh2.6) }\end{array}$ \\
\hline $\begin{array}{l}\text { Teacher } \\
\text { (T2) }\end{array}$ & $\begin{array}{l}\text { Please try } \\
\text { once again } \\
\text { mom (Th2.7) }\end{array}$ & $\begin{array}{l}\text { Sorry mom. Thank } \\
\text { you. (Rh2.7) }\end{array}$ \\
\hline $\begin{array}{l}\text { Parent } \\
(\mathrm{P} 2)\end{array}$ & I (Th2.8) & $\begin{array}{l}\text { don't want to try } \\
\text { anymore. }(\operatorname{Rh} 2.8)\end{array}$ \\
\hline
\end{tabular}

The conversation 3 emphasizes more on the school fee as the parent's obligation to pay back the contribution given by the teacher and school in educating the children. In the conversation above, the Rheme of the previous statement becomes the starting point of the theme of the following statements. This implies that both speaker agrees on which topic that would be discussed in the discourse. The conversation starts by mentioning that the child of the parent has not paid the school's fee (Rh3.1) which is later confirmed true by the parents (Th3.2).

Surprisingly, P3 confirms the payment in Rh3.3 after sending a picture of particular amount of money. His confirmation is put in the Rheme because he wants T3 to note his message as a New information responding to the query. Later, P3 restates Rh3.3 as Th3.5 to strengthen his statements and to indicate that he is fully aware of the information given to the T3. Knowing that the statement may confuse T3, P3 adds his explanations in Rh3.5regarding to the reasons of his act in paying the school fee.
Table 3: Analysis on Conversation 3

\begin{tabular}{|c|c|c|}
\hline Speaker & Theme & Rheme \\
\hline $\begin{array}{l}\text { Teacher } \\
\text { (T3) }\end{array}$ & $\begin{array}{l}\text { Good evening } \\
\text { Sir. (Student's } \\
\text { name) 's school } \\
\text { fee (Th3.1) }\end{array}$ & $\begin{array}{l}\text { has not been } \\
\text { paid yet. }(\mathrm{Rh} 3.1)\end{array}$ \\
\hline \multirow[t]{2}{*}{$\begin{array}{l}\text { Parent } \\
\text { (P3) }\end{array}$} & Yes Sir (Th3.2) & $\begin{array}{l}\text { Please wait } \\
\text { (Rh3.2) }\end{array}$ \\
\hline & $\begin{array}{l}\text { (Sending the } \\
\text { picture of the } \\
\text { money) This is } \\
\text { Sir, (Th3.3) }\end{array}$ & $\begin{array}{l}\text { Paid already } \\
(\mathrm{Rh} 3.3)\end{array}$ \\
\hline $\begin{array}{l}\text { Teacher } \\
\text { (T3) }\end{array}$ & What (Th3.4) & $\begin{array}{l}\text { Do you mean? } \\
\text { (Rh3.4) }\end{array}$ \\
\hline $\begin{array}{l}\text { Parent } \\
(\mathrm{P} 3)\end{array}$ & $\begin{array}{l}\text { Yes, that's the } \\
\text { school fee Sir } \\
\text { (Th3.5). }\end{array}$ & $\begin{array}{l}\text { My kid has his } \\
\text { assignment and } \\
\text { material } \\
\text { through WA, he } \\
\text { schools at home, } \\
\text { why can't I pay } \\
\text { the school fee } \\
\text { through WA } \\
\text { then? I put my } \\
\text { kids at school } \\
\text { because I am } \\
\text { busy. (Rh3.5) }\end{array}$ \\
\hline
\end{tabular}

Refusing to pay the school fee literally indicate that parents has seen that teacher does not deserve to get his contribution money. For the parent, online learning means that there is no teaching-learning process because that process should be handled by the teacher. The parent even emphasized that teaching his kids is not his responsibility because he has handed over the importance of learning towards the teacher's hands due to his business.

Table 4: Analysis on Conversation 4

\begin{tabular}{|l|l|l|}
\hline Speaker & Theme & Rheme \\
\hline $\begin{array}{l}\text { Teacher } \\
\text { (T4) }\end{array}$ & $\begin{array}{l}\text { Dear mom, } \\
\text { for today's } \\
\text { activity, } \\
\text { (Th4.1) }\end{array}$ & $\begin{array}{l}\text { I have posted the } \\
\text { assignment on Bim } \\
\text { Announcement KG }\end{array}$ \\
& $\begin{array}{l}\text { B. You can print HW and } \\
\text { EX, then put them on the } \\
\text { workbook, or you can just } \\
\text { hand write them. } \\
\text { Tq mom (hug emoticon), } \\
\text { Stay safe and healthy my } \\
\text { dear students and moms } \\
\text { (kiss emoticon \& smile } \\
\text { emoticon). } \\
\text { (Rh4.1) }\end{array}$ \\
\hline
\end{tabular}


After discussing the learning media, parent's role and the school fee, the $4^{\text {th }}$ conversation evaluates the teacher's role from the perspective of the parents.

\begin{tabular}{|l|l|l|}
\hline $\begin{array}{l}\text { Parent } \\
\text { (P4) }\end{array}$ & $\begin{array}{l}\text { Miss, I am } \\
\text { not a } \\
\text { teacher, } \\
\text { (Th4.2) }\end{array}$ & $\begin{array}{l}\text { you, the teacher, are } \\
\text { enjoying life asking } \\
\text { us to teach our kids. } \\
\text { If I were smart, I'll } \\
\text { sign myself up as a } \\
\text { teacher. We pay for } \\
\text { teacher to teach our } \\
\text { son. It's better for } \\
\text { you to cancel sending } \\
\text { the materials because } \\
\text { it stresses me out. } \\
\text { (Rh4.2) }\end{array}$ \\
\hline
\end{tabular}

Conversation 4 is started by directly commanding P4 to do as $\mathrm{T} 4$ wish. Unlike the $1^{\text {st }}$ conversation, parent in the $4^{\text {th }}$ conversation does not explicitly refuse the request. Rather, she clarifies both of teacher's and parent's roles in the given discourse. Her clarification is placed under the Theme framework as a mutual shared knowledge to indicate that both of speakers have known each of their role. This role is the starting point of the New information discussed in Rh4.2. Furthermore, P4 put her judgment towards current situation. She claims that teacher in online school program has taken an advantage because teacher just commanding while the parent does the hard work in learning-teaching process. $\mathrm{P} 4$ even emphasizes that the point of sending the child to the school is because of the parents' inability to teach child. She also restates that it is not the parents' responsibility to educate the kid because the main reason they pay the school fee is to hand over the task of education towards the school and teacher.

\subsection{Discussion}

The analysis reveals the education's cultures in Indonesia and uncover the clear distinction of parent and teacher responsibilities before the pandemic hits us. Through the findings above, it can be implied that the education system in Indonesia has been school centric and teacher driven. Commonly, parents send the children to the school while they're going to work. Therefore, the responsibility of educating the children has been handled by the school with no clear parameter on how far the parents should share the responsibility. This has made the teaching-learning process in any educational aspect becomes school dependent.
However, covid-19 pandemic has changed the educational culture in all levels. Following the recommendation of Indonesian Pediatrician Association, Indonesia government has suggested schools to implement "school from home" system. This system emphasizes parent and teacher to work together as a team in educating the children. While the teacher provides the material and structures the assignment, the task for accompanying the children in teaching-learning process is handed over to the parents.

Unfortunately, the hand-over responsibilities in pandemic era has not been welcomed by the parents. Through the findings above there are four things that burdens the parents in conducting "school from home" activity. They are: the use of learning media, the psychological impact that parent has to deal with, the demands to pay tuition fee, and the role of parent and teacher in educating the children.

As important as transferring knowledge through teacher's lecture, the use of learning media is regarded as one of the crucial element in succeeding the educational process. Several claims have been made to support the statement. They are; helping the students to gain the knowledge easier, providing longer retention of the gained knowledge, and motivating the students because it enhances the students' interest [13]. Unfortunately, these notions have not been realized by the parents when the responsibility of education is handed over to them. Thus, when parents refuse to provide learning media, they seem to harden the children's process of gaining knowledge. When the children feel difficult to understand, the job of the educator or teacher will also be harder. This condition is surely not expected by the parents in educating the children at home.

Another negative proposition drawn through the implementation of online learning is the psychological impact felt by parents when they take the role as the teacher at home. Parents feel burdened and stressed out when they have to teach their children. Indeed, human possesses several roles depending on the discourse they are in. In this case, the children possess the role as the students when it comes to educational atmosphere. The parent's objection then mirrors their refusal in taking their role in the given discourse. It seems that in the educational discourse, the stakeholders of the discourse are merely the children and the teacher. Parents are excluded from the context. This perspective deplores both of parents and 
children. Active involvement of parents has been proven to strengthen parent-children's attachment because it makes the students work harder as they naturally eager to make the parents proud [14].

Another factors discussed within the discourse of school from home is the tuition fee. Parent's objection in paying the tuition fee has discovered another perspective in the education's culture in Indonesia. Their objection implies that they deem the schooling system as one of the transactional services where parents are the customers and teachers \& schools are the service providers. As the nature of the transactional process, spending particular amount of money means leaving all the tasks and jobs to the service providers. Therefore, the parents feel disheartened to teach the kids at home because they feel that it is futile to pay if they have to be the customers and the service providers at the same time. They regard school and teacher has failed to meet their needs as the customers.

As those complains are not enough, the last factors backgrounding the parents' disappointments in conducting "school from home" is the unclear distinction of teacherparent role in the education's context. Teacher is seen as the sole stakeholder in educating the children. Thus, when "school from home" is conducted, the parents confuse the teacher's role as the main participant in transferring the knowledge. The parents' clarification by negating themselves as the teacher indicate that they are not willing to be included as the main participant in succeeding the knowledge transfer process. Their refusal is made based on the reason that at the very first beginning, they notice that they have no ability in making their children smart and full of knowledge. Therefore, when they notice this state of affair, they choose teacher, as the smart and full of knowledge person, to educate their children. Instead of adjusting to the current situation and equipping themselves with a handful of knowledge, parents tend to complain when the responsibility of making the children smart is shared.

\section{CONCLUSION AND SUGGESTION}

The pandemic of covid-19 has revealed our long times' education's culture. Before the pandemic, the parent has been in a comfort zone of exclusivity in education discourse. The teachers and schools have fully handled the job of educating and teaching. This exclusivity hardens the process of gaining knowledge when "school from home" is implemented. They feel aggrieved when the online learning system insists the parents to have multiple roles as a co-teacher. The exclusivity is harming the children in gaining knowledge. Therefore, the renovation of the education's system involving the parent is on an urgent call.

\section{REFERENCES}

[1] G. Sapungan \& R. Sapungan, "Parental Involvement in Child's Education: Importance, Barriers and Benefits". Asian Journal of Management Sciences \& Education. 3(2). 2014 4248.

[2] A. Ceka, \& R. Murati, "The Role of Parents in the Education of Children". Journal of Education and Practice, 7(5) 2016 61-64.

[3] K. Yulianti, E.J.P.G. Denessen, \& W. Droop, Indonesian parents' involvement in their children's education: A study in elementary schools in urban and rural Java, Indonesia, 2019

[4] L. Potter, "Ideological representations and ThemeRheme analysis in English and Arabic news reports: a systemic functional approach", Functional Linguistics, 3(1) 2016 1-20. DOI: https://doi.org/10.1186/s40554-016-0028-y

[5] G. Stella \& S. Gunawan, "AN ANALYSIS OF THEME AND RHEME USED IN THE FIVESTAR HOTELS'WEB SITES IN SURABAYA," Kata Kita, 5(1) 2017 54-59. DOI: https://doi.org/10.9744/katakita.5.1.54-59

[6] I.N. Sinaga, Theme-Rheme Analysis on the Jakarta Post Newspaper: Interpolations, in Preposed Attributive, And Reported Clause. Proceedings of EEIC, 2, 32-36, 2019

[7] Gerott and Wignell. Making Sense of Functional Grammar. Gerd stabler, 1994

[8] Wang, "Theme and rheme in the Thematic Organzation of Text: Implication for tEcahing Academic Writing”, Asian EFL Journal, (9)1 2007

[9] Adawiyah. An Analysis of Theme and Rheme Organization on Academic Essay Written by the Fift Semester Students of UIN Raden Patah Palembang. Undergraduate thesis, UIN Raden Patah Palembang, 2017

[10] Yang, "Thematic Progression Analysis in teaching Exploration Writing", English Language Teaching, 1 (1), 2008 29-33.

[11] Halliday and Matthiessen, An Introduction to Functional Grammar (3thed), New York: NY10016, 2004

[12] M.A.K. Halliday, 1976. Theme and information in the English clause. In Halliday: 
System and function in language, ed. G. Kress, London: Oxford University Press, 1976

[13] A. A. Naz, \& R. A. Akbar, "Use of media for effective instruction its importance: some consideration", Journal of elementary education, 18(1-2) 2008 35-40.

[14] Ntekane. (2018) Parental Involment in Education. DOI: $\underline{10.13140 / R G .2 .2 .36330 .21440}$ 